\title{
REALITAS MASYARAKAT INDONESIA DALAM MEDIA MASSA
}

\section{Asep Soegiarto}

\begin{abstract}
The mass media, not just serve as the grantor information, the amusement and social control or fourth power as a nation ( the four estate ), but also as a form of public opinion who directs and public opinion in the issues developing world. Reporters when covering an event and writing it has a tendency to subjective and biased. The problem of bias in the press is not a matter of who, or of what system, is supported. The problem is that the bias exists, and the system through which our media operates seems guaranteed to ensure that bias will continue. Journalistic product in the media is not the whole of the reality of the society but only parts of reality that described as realities. In a so-called media image. The news media in a determined by its media ownership, and other factors it has a very significant role aside from bias a journalist
\end{abstract}

Key Word: Objectivity, Media Biased, Media Image

\section{Pendahuluan}

Tahun 1997 merupakan merupakan salah satu tahun terpenting dalam tonggak Sejarah Perkembangan Bangsa Indonesia. Ditahun tersebut, terjadi peristiwa yang tak terlupakan dan maha penting bagi manusia Indonesia yang hidup di era itu. Setelah lebih kurang 30 tahun berkuasa, dengan system Demokrasi Pancasilanya, akhirnya Presiden Soeharto, melalui demonstrasi besar-besaran mahasiswa hampir diseluruh Indonesia, akhirnya mengundurkan diri (lengser) dari kursi kepresidenan Republik Indonesia, dan digantikan oleh Prof. DR. BJ Habibie. Setelah kejatuhan Soeharto, jargon reformasi menjadi kata yang yang terdengar setiap harinya, baik melalui pembicaraan warung kopi maupun melalui media massa.

Nuansa kebebasan yang tadinya hampir tak ada (jika dapat dikatakan dengan ekstrim tak pernah ada) selama 30 tahun pemerintahan Presiden Soeharto, mewarnai berbagai sisi kehidupan masyarakat Indonesia. Euforia demokrasi demikian derasnya bertiup, sehingga tidak jelas lagi antara kebebasan dengan frame (demokrasi), yaitu tata kehidupan yang memenuhi aturan-aturan kehidupan sosial 
politik dan kemasyarakatan yang telah diatur dan disepakati bersama, dengan kebebasan tanpa frame (anarkis), ditandai dengan perebutan lahan secara sepihak olah masyarakat ataupun menurunkan penumpang seenaknya di jalan bebas hambatan, maupun tindakan-tindakan lainnya yang menyalahi aturan kehidupan bermasyarakat lainnya.

Fenomena kebebasan ini juga melanda Media massa di Indonesia. Di era Presiden Soeharto, dalam melaksanakan aktifitas jurnalisme, hampir semua media bertakwa (tunduk dan patuh) pada UU Pokok Pers, KUHP yang mengatur tentang penyebaran informasi, serta Kode Etik PWI, dan telepon pejabat Departemen Penerangan. Terkecuali beberapa media yang kemudian dikenakan pembredelan oleh rezim Soeharto, seperti majalah Tempo, Prioritas, Suara Pembaharuan dan lainlain. Di era reformasi, media massa dan pekerja-pekerja serta pemilik media, dapat secara bebas mencari, menulis dan menginformasikan kepada khalayak tentang berbagai hal. Pendapat bahwa media sebagai kekuatan keempat dalam Negara demokrasi, mewujud dalam aktifitas jurnalistik di Indonesia, mulai dari perang opini tentang pemilu yang dipercepat, lepasnya propinsi ke 27 yaitu Timor Timur sampai dengan infotainment yang merebut ruang pribadi seseorang menjadi konsumsi sehari-hari khalayak media dalam berbagai bentuk kemasan informasi.

Namun dalam perkembangannya, tampilan media ini menuai reaksi dari khalayak mulai dari keberatan tentang tampilan media yang vulgar yang disampaikan melalui surat pembaca, somasi yang dilayangkan oleh seseorang yang merasa dirugikan kepada media, semisal Tomi Winata kepada Majalah Tempo dan yang ekstrim yaitu tindakan penyerbuan sekelompok orang ke kantor redaksi media, yang merasa dirugikan oleh pemberitaan media tersebut, seperti penyerbuan kantor redaksi Majalah Tempo oleh sekelompok orang dari Tanah Abang. Peristiwa penyerbuan kantor redaksi media yang terakhir menimpa Indo Pos. Secara hokum tindakan penyerbuan salah! Dengan dalih apapun hal itu tidak ada pembenarannya. Terlepas dari semua itu, ada hal yang menarik untuk dikaji lebih lanjut dari gejala reaksi khalayak terhadap pemberitaan media, yaitu bagaimanakah suatu media 
menampilkan realitas masyarakat secara obyektif, netral, dan akurat dalam bentuk produk jurnalistik?

Media massa, dalam hal ini surat kabar, pada masa kini tidak hanya sekedar berfungsi sebagai pemberi informasi, hiburan dan kontrol sosial atau sebagai kekuatan keempat suatu negara (the four estate), tetapi juga sebagai pembentuk opini publik yang mengarahkan pendapat masyarakat dalam peristiwa maupun isu-isu yang berkembang.

Revolusi media pada saat ini memungkinkan terpenuhinya hak tiap orang untuk mengetahui. Namun di pihak lain muncul masalah dalam pemberitaan yang menyangkut kaidah dasar jurnalisme, yakni obyektifitas suatu berita, keharusan untuk bersikap netral dan meliput dari sisi kedua belah pihak (cover both side) yangmerupakan imbas dari adanya pemihakan media atas dasar ideologi dan nilainilai tertentu.

Rivers dan Mathews (1994:98) menjelaskan bahwa sedekat apapun pendekatan wartawan terhadap obyektifitas, obyektifitas tetaplah sebuah ilusi. Pendapat yang sama juga diutarakan oleh Tiffen (1978:94). Ia mencatat satu gagasan umum adalah bahwa obyektifitas adalah tujuan yang diinginkan, walaupun itu secara kemanusiaan mustahil untuk mencapainya. One common idea is that objectivity is the desired aim, although it is humanly impossible to achieve.

Ini sesuai dengan pendapat Agus Sudibyo (Kompas, 5/04/2003), peneliti media dari ISAI (Institut Studi Arus Informasi), bahwa pandangan kritis dalam ranah studi media meniscayakan terjadinya pemihakan media atas dasar ideologi dan nilai-nilai tertentu. Sulit mengharapkan media atau jurnalis benar-benar netral dalam melihat suatu konflik karena ideologi adalah sesuatu yang inheren dalam tiap individu, tanpa terkecuali individu media.

Hal yang hampir senada dikemukakan oleh Tony Bennet (Eriyanto, 2003 : 37) dengan menyatakan, media sebagai agen konstruksi sosial mendefinisikan realitas sesuai dengan kepentingannya. Dalam pandangan Kritis, media juga dipandang sebagai wujud dari pertarungan ideology antara kelompok-kelompok yang ada dalam masyarakat. Media dipandang sebagai arena perang antar kelas. Media dapat 
dilihat sebagai forum bertemunya semua kelompok dengan sudut pandang yang berbeda-beda. Dalam pandangan kritis, pada akhirnya kelompok dominanlah yang lebih menguasai pembicaraan dan menentukan arena wacana.

\section{Media Massa Sebagai Arena Pertarungan Ideologi}

Suatu teks merupakan pencerminan dari ideologi penulisnya. Seorang wartawan ketika menulis sebuah berita, secara sadar maupun tidak sadar, menawarkan ideologinya kepada pembaca dengan mengajak pembaca untuk menempatkan dirinya sesuai dengan kehendak penulis. Teks berita yang diproduksi oleh wartawan akan selalu mencerminkan ideologinya dan akan seperti pedagang yang menawarkan barang dagangannya (ideologi) untuk memanipulasi pembaca seperti yang diharapkannya.

Sarana yang efektif dalam merubah, membentuk dan memperteguh persepsi seseorang mengenai peristiwa yang terjadi adalah dengan menggunakan media. Seperti yang dikatakan oleh Eriyanto (2001:96) mengatakan adanya ideologi yang sama menyebabkan tidak ada beda pandangan antara penulis dengan pembaca. Akibatnya, nilai-nilai pandangan yang dibawa oleh pembuat teks bukan hanya disetujui oleh pembaca, lebih jauh dinikmati dan dikonsumsi oleh pembaca teks.

Ideologi tidak akan lepas di dalam suatu wacana. Ideologi adalah bagian yang terpenting dari media massa. Melalui media massa seorang penulis teks beserta ideologinya bertemu dengan pembacanya, yang sangat mungkin memiliki ideologi tersendiri. Dengan kata lain menjadikan daerah tersebut sebagai medan pertempuran antara ideologi penulis dengan ideologi pembaca. Gramsci, seperti yang disitir Sobur (2002:30), mengatakan bahwa media merupakan arena pergulatan antar ideologi yang saling berkompetisi. Hal tersebut sejalan dengan pendapat Eriyanto (2001:14) yang mengatakan wacana tidak dipahami sebagai sesuatu yang netral dan alamiah, karena di dalamnya selalu terkandung ideologi untuk mendominasi dan berebut pengaruh.

\section{Objektifitas Wartawan dan Kebijakan Redaksional}


Suatu berita ketika disusun dan dikemas oleh wartawan surat kabar memiliki kualitasnya tersendiri. Nugraheni (Jurnal Ilmu Komunikasi 'Citra' Univ. Jayabaya Vol. 02, No. 4, 2002) mencatat ada beberapa unsur yang akan menentukan kualitas suatu berita. Kualitas berita ini meliputi obyektifitas, keakuratan, keseimbangan dan tidak memihak. Obyektifitas adalah kualitas berita yang meliputi dimensi faktutalitas (termasuk kejujuran dan relevansi) dan dimensi ketidakberpihakan (termasuk keseimbangan, nonpartisanship dan penyajian secara netral).

Banyak orang sering mempertanyakan keobyektifan seorang wartawan dalam menjalankan tugasnya. Ada orang yang menyatakan bahwa wartawan harus menekankan prinsip atau kaidah dasar jurnalisme yakni keobyektifan. Ada juga yang menyatakan bahwa obyektifitas adalah sebuah kemustahilan. Rivers dan Mathews (1994:99) berpendapat bahwa wartawan tidak bisa bersikap obyektif. Tetapi semakin baik seorang wartawan, ia semakin mampu mendekati obyektifitas. Sedangkan Wilson (1989:133) menjelaskan believing that they should report the truth "as they see it," these reporters became personally and emotionally involved in the events they covered. Mempercayai bahwa mereka harus melaporkan yang sebenarnya "seperti yang mereka lihat", reporter ini menjadi terlibat dalam kejadian-kejadian yang terjadi secara pribadi dan emosional.

Lebih lanjut, Tiffen menjelaskan (1978:189), Sikap yang paling umum diantara wartawan aktif adalah bahwa sikap individu, yang tak bisa diacuhkan, mempengaruhi pelaporan. Tetapi ada juga perasaan kuat bahwa suatu wartawan profesional perlu memperkecil / mengatasi / mengimbangi prasangkanya, untuk mencoba menjadi seobjektif mungkin. Sikap ini yang menjadi karakteristik mayoritas wartawan. Hal itu dapat diargumentasikan bahwa cara berpendirian ini hanya suatu semboyan pembelaan diri yang dapat berarti banyak hal yang berbeda dalam praktek. Tetapi adalah penting untuk mencatat kelazimannya dan kesungguhan hati yang nyata dari mereka yang mengutamakannya.

Berita merupakan laporan mentah yang kemudian diolah sehingga enak dibaca. Di sini harus dapat dibedakan mana pendapat dan fakta. Wartawan hanyalah pewarta kejadian atau fakta sehari-hari. Obyektifitas dalam proses produksi berita secara 
umum digambarkan sebagai tidak mencampuradukkan antara fakta dan opini. Berita adalah fakta dan karenanya dalam proses pencarian dan penulisan berita, sama sekali tidak boleh terdapat opini (Eriyanto, 2002:113). Hal senada juga dikemukakan oleh Oetama (2001:144) bahwa berita bukanlah kejadian sendiri. Berita ialah laporan tentang sesuatu kejadian yang aktual dan bermakna. Kejadiannya sendiri merupakan sesuatu yang obyektif, sedangkan bagaimana kejadian itu dipilih menjadi berita atau dilaporkan sebagai berita, jelas sesuatu yang subyektif.

Astraatmaja, Ketua Dewan Pers, menulis mengenai penyajian berita yang bertanggung jawab kepada masyarakat. Ia (Kompas, 26 Agustus 2003), menyatakan karena pers bertanggung jawab kepada khalayak atau publik, maka para wartawan dituntut bukan hanya menyajkan fakta, melainkan juga kebenaran tentang fakta itu. Berita bukan sekadar untuk di jual, melainkan - dan terutama - demi kepentingan umum. Oleh karena demi kepentingan umum itulah diperlukan kebenaran, maka pers perlu menyajikan kebenaran.

Wartawan, ketika meliput suatu peristiwa dan menulisnya memiliki kecenderungan untuk subyektif dan bias. Dengan kata lain, wartawan memiliki biasnya tersendiri ketika berhadapan dengan peristiwa yang diliputnya. Mereka melakukannya melalui pemilihan kata-kata yang tepat untuk menggambarkan suatu peristiwa, fakta-fakta mana yang yang diambil dan narasumber yang layak diwawancarai karena sudah diketahui pandangannya tentang suatu peristiwa tersebut.

Akan tetapi, ternyata masalah bias dalam pers tidak persoalan siapa atau sistem apa yang mendukung. Masalahnya adalah bahwa bias selalu ada, dan sistem dimana pers kita dioperasikan terlihat menjamin untuk memastikan bahwa bias akan terus berlanjut. Seperti yang dinyatakan oleh Danuta Reah dalam The Language of Newspapers (1998:10),

The problem of bias in the press is not a matter of who, or of what system, is supported. The problem is that the bias exists, and the system through which our press operates seems guaranteed to ensure that bias will continue.

George Gerbner, dalam McQuail dan Windhal (1981) menggambarkan proses persepsi dan produksi pesan yang dapat menjelaskan kepada kita seberapa baik 
hubungan antara realitas dan berita dalam suatu model proses komunikasi (lihat gambar). Model itu menjelaskan bahwa bentuk jadi suatu produk jurnalistik apakah itu berita, reportase, feature dan lain-lain bukanlah gambaran yang utuh dari realitas. Dia merupakan hasil dari persepsi sang wartawan terhadap realitas yang menjadi objek produk jurnalistik itu. Lebih lanjut model ini menyatakan bahwa proses komunikasi dapat dianggap bersifat subyektif, selektif, bervariasi, tidak dapat diduga, dan sistemnya bersifat terbuka.

Wartawan turut mempengaruhi proses pemberitaan suatu media karena wartawan adalah individu yang sudah terbentuk oleh lingkungan dan memiliki persepsi sendiri dalam melihat realitas. Tetapi, media jugalah yang akhirnya menjadi gatekeeper karena sebuah media memiliki kebijakan redaksional yang akan sangat mempengaruhi proses pemberitaan media yang bersangkutan.

Oetama (2001:146) mengartikan kebijakan redaksional sebagai visi, pandangan pokok surat kabar yang bersangkutan. Visi dasar itu menguraikan sejumlah nilai. Sejumlah nilai pokok itu menjadi kerangka acuan dalam menentukan kebijakan redaksional. Ia selanjutnya menulis bahwa kebijakan redaksional menjadi pedoman dan ukuran dalam menentukan kejadian macam apa yang oleh surat kabar itu patut diangkat serta dipilih untuk menjadi berita maupun bahan komentar.

Selain dari pada itu, pemilik surat kabar memiliki peran yang juga besar. Reah (1998:8) menuliskan bahwa pemilik surat kabar memiliki kekuatan yang sangat besar untuk mempengaruhi pemberitaan di dalam surat kabar.

"An important factor in the existence of a free press is ownership. The owner of a newspaper has the power to influence the content of the paper, its political stance and its editorial perspective. There has probably never been a time when a newspaper owner did not influence in some way what appeared in that paper. A diverse range and a large number of newspaper owners seems to be an important factor in ensuring that as wide a range of views and interests is represented in the press."

Ketiga pihak tersebut - wartawan, redaksi dan pemilik media - diwakili oleh kelompok idealis dan kelompok bisnis. Seperti yang dikatakan Ishadi SK dalam Orasi Ilmiah Wisuda XVIII Universitas Sahid Jakarta Tahun Akademik 2003/2004. Ia menyebutkan interaksi di dalam media itu khususnya di news room sebagai interaksi antara kekuatan-kekuatan yang cenderung pada kelompok yang mengajukan 
pemikiran idealis, dan kelompok lain yang mengutamakan kepentingan bisnis. Selanjutnya ia menyatakan bahwa pemikiran idealisme berlandaskan pada semangat pemahaman pada konsep dasar demokrasi konstitusi, norma agama, etika, nilai moral dan pendidikan. Sementara pemikiran bisnis bertumpu pada semangat kompetisi, profit, market driven, uses and gratifications of the media. Seperti yang disitirnya dari Makarim, "para wartawan semakin menempatkan aspek bisnis sebagai bagian integral dari kegiatan jurnalistik mereka - bila mereka tidak ingin media mereka tersingkir dari pasar."

Paparan ini mengambarkan dengan jelas bahwa produk jurnalistik dalam media bukanlah bentuk utuh dari realitas dalam masyarakat, tetapi hanyalah penggalanpenggalan realitas yang digambarkan seakan realitas. Dalam komunikasi disebut

sebagai citra media. Citra media bukanlah dan mungkin sangat berbeda dengan citra realitas. Selain itu, arah pemberitaan dalam suatu media ditentukan oleh kebijakan redaksional media dan faktor kepemilikan, memiliki peranan yang sangat signifikan, selain dari bias seorang wartawan.

\section{DAFTAR PUSTAKA}

\section{Buku}

Abrar, Ana Nadhya. 1995. Mengurai Permasalahan Jurnalisme. Jakarta: Pustaka Sinar Harapan.

Eriyanto. 2001. Analisis Wacana: Pengantar Analisis Teks Media. Yogyakarta: LKiS. .2002. Analisis Framing: Konstruksi, Ideologi, dan Politik Media. Yogyakarta: LKiS.

Nimmo, Dan. 1989.Komunikasi Politik, Bandung: CV Remadja Karya.

Nugroho, B., Eriyanto, Frans Surdiarsis. 1999. Politik Media Mengemas Berita. Jakarta: Institut Studi Arus Informasi.

Oetama, Jakob.2001. Pers Indonesia: Berkomunikasi Dalam Masyarakat Tidak Tulus. Jakarta: Penerbit Buku Kompas. 
Reah, Danuta. 1998.The Language of Newspapers. New York: The Routledge Intertext Series.

Sobur, Alex.2002. Analisis Teks Media: Suatu Pengantar untuk Analisis Wacana, Analisis Semiotik, dan Analisis Framing. Bandung: PT Remaja Rosdakarya.

Siebert, Fred S.1986.Empat Teori Pers. Alih bahasa Drs. Putu Laxman Sanjaya Pendit. Jakarta: PT Intermasa.

Straubhaar, Joseph D.2000. Media Now: Communication Media In The Information Age. Wadsworth / Thomson Learning.

Tiffen, Rodney.1978.The News From South East Asia, The Sociology of News Making. Singapore. Institute of South East Asia Studies.

Wahyudi, J.B. 1991. Komunikasi Jurnalistik. Bandung: Penerbit Alumni.

Wright, Charles R. 1998. Sosiologi Media Massa. Bandung: PT Remaja Rosdakarya.

\section{Sumber lain:}

Astraatmaja, Atmakusumah (Ketua Dewan Pers (2000-2003)."Pers Mencari Kebenaran; Benarkah PM Khrushchev Memukulkan Sepatunya ke Meja di Sidang MU PBB?". Kompas, 26 Agustus 2003.

Nugraheni, Yuli. "Orientasi Pemberitaan Harian Ekonomi Mengenai Masalah Otonomi Daerah". Jurnal Ilmu Komunikasi “Citra” Vol. 02 No. 4 Tahun 2002.

SK, Ishadi. "Peranan Televisi Di Era Reformasi Dalam Mencerdaskan Kehidupan Bangsa: Antara Realita Dan Harapan". Orasi Ilmiah Wisuda XVIII Universitas Sahid Jakarta Tahun Akademik 2003/2004. Jakarta. 22 Juni 2004. 